\title{
POTENSI OBJEK DAN DAYA DUKUNG KAWASAN OBJEK WISATA GOA H'WANG DI KABUPATEN MALUKU TENGGARA
}

\author{
OBJECT POTENTIAL AND CARRYNG CAPASITY OF GOA H'WANG TOURISM OBJECT \\ AREA IN MALUKU TENGGARA DISTRICT \\ Oleh: \\ Ongky Safari $^{1,}$ C.K.Pattinasaranny ${ }^{2}$,Yosevita.Th.Latupapua ${ }^{3}$ \\ ${ }^{1,2,3}$ Program Studi Kehutanan Jurusan kehutanan Fakultas Pertanian, Unpatti Poka-Ambon \\ Email: ongkysafari@yahoo.com \\ \begin{tabular}{|l|l|}
\hline Diterima: 5 Mei 2020 & Disetujui:12 Juni 2020 \\
\hline
\end{tabular}
}

\begin{abstract}
Abstrak
Tujuan penelitian ini adalah untuk mengetahui kondisi potensial dan daya dukung kawasan objek Goa H'wang di Kabupaten Maluku Tenggara. Penelitian ini menggunakan desain penelitian deskriptif. Populasi penelitian adalah masyarakat yang memiliki keterkaitan dengan pengelolaan objek wisata Goa H'wang. Sampel diambil secara purposive sampling sebanyak 10 orang, terdiri dari pengelola Goa, penjual tiket, masyarakat penjual makanan dan minuman, juru gua. Pengumpulan data dilakukan melalui observasi, wawancara terstruktur, studi pustaka, dan dokumentasi. Analisis data dilakukan melalui analisis kualitatif dan kuantitatif menggunakan pembobotan / penskoran daya tarik objek dengan menggunakan kriteria Penilaian Analisis Atraksi Objek Goa. Hasil penelitian menjelaskan daya tarik potensial yang dapat dinikmati pengunjung adalah panorama di sekitar goa yang masih nampak alami, serta memiliki keanekaragaman jenis pohon dan satwa, didukung pula dengan interior goa berupa stalatite. dan stalamite. Daya dukung fisik kawasan wisata Goa untuk menampung pengunjung berkisar 110 orang / hari. Batasan daya dukung tersebut belum melebihi daya dukung kawasan jika dikaitkan dengan jumlah kunjungan per hari yang hanya berkisar 20-30 pengunjung.
\end{abstract}

Kata Kunci: Objek Potensial, Daya Dukung Kawasan, Gua H'wang

\begin{abstract}
The purpose of this study was to determine the potential conditions and carrying capacity of the H'wang Goa object area in Southeast Maluku district. This research uses descriptive research design. The research population is the community that has a relationship with the management of the Goa H'wang object. Samples were taken by purposive sampling as many as 10 people, consisting of Goa managers, ticket sellers, food and beverage seller communities, cave interpreters. Data collection is done through observation, structured interviews, literature studies, and documentation. Data analysis was performed through qualitative and quantitative analysis using weighting / scoring of the attractiveness of objects by using the Object Attraction Analysis Assessment criteria of Goa. The results of the study explain the potential attraction that can be enjoyed by visitors is the panorama around the cave that still seems natural, and has a diversity of species of trees and animals, also supported by the interior of the cave in the form of stalatite and stalamite. The physical carrying capacity of the Goa tourist area to accommodate visitors ranges from 110 people / day. The carrying capacity limit has not exceeded the carrying capacity of the region if it is connected with the number of visits per day which is only around 20-30 visitors.
\end{abstract}

Keywords: Potential objects, Regional carrying capacity, H'wang Cave

DOI: $10.30598 /$ jhppk.2020.4.2.172

ISSN ONLINE: 2621-8798

Page 172 


\section{PENDAHULUAN}

Negara Indonesia merupakan Negara kepulauan yang memiliki kekayaan sumber daya alam baik di daratan maupun di lautan yang sangat melimpah. Indonesia memiliki potensi wisata yang cukup besar dengan keindahan alam mulai dari pantai hingga pegunungan, keindahan alam tersebut ditunjang dengan adanya keanekaragaman budaya, flora dan fauna, dan landscape yang tersebar di seluruh pelosok Nusantara.

Maluku Tenggara memiliki potensi flora, fauna, tipe ekosistem yang beragam serta fenomena-fenomena alam yang indah, semua ini dapat menjadi daya tarik wisata yang tinggi. Dengan adanya potensi-potensi sumberdaya alam yang indah dan unik ini membuat Tual dalam beberapa tahun pasca kerusuhan 19992002 telah dapat kembali menata keberadaan ekonomi daerah setempat melalui kegiatan wisata alam ini. Objek wisata pantai seperti Pantai Ngurbloat, Diur, Ngursarmadan, dan Pemandian Evu merupakan kawasan pengembangan prioritas bagi kegiatan wisata di

Kabupaten Maluku Tenggara memiliki keragaman objek daya tarik pantai dan budaya yang terkenal. Pesosna keindahan pasir panjang "ngurbloat" pantai putih dengan butiran pasir yang sehalus tepung, menjadi daya tarik potensial dalam menarik minat kunjungan wisatawan untuk datang ke destinasi tersebut. namun tidak hanya daya tarik pantai yang dapat dikunjungi, gua H'wang yang berada di Desa Letvuan dan jaraknya tidak

Daya tarik yang diberikan menimbulkan sensasi tersendiri bagi para wisatawan yang menikmatinya sehingga tidak menutup kemungkinan pariwisata gua memiliki resiko kerusakan lingkungan gua sendiri apabila jika tidak dikelola dengan baik dan mengabaikan

Penilaian daya dukung kawasan merupakan salah satu tindakan penting guna mendukung pariwisata berkelanjutan. Pengelolaan dengan memperhatikan daya dukung dapat meminimalisasi dampak negatif yang akan terjadi terhadap lingkungan.

\section{METODE PENELITIAN}

Penelitian ini dilaksanakan di objek wisata Gua H'wang Desa Letvuan, Kecamatan Hoat Alat dan Bahan Penelitian
Indonesia termasuk salah satu daerah tujuan wisata alam di dunia. Bertolak dari penjelasan dan kenyataan tersebut pemerintah Indonesia telah memutuskan kepariwisataan dalam Undang-Undang RI No. 10 Tahun 2009. Pariwisata adalah berbagai macam kegiatan wisata yang didukung oleh berbagai fasilitas serta layanan yang disediakan oleh masyarakat, pemerintah dan pihak swasta (Baulu, 2013).

daerah. Kerjasama antar stakeholder seperti pemerintah, LSM dan berbagai pihak terkait diperlukan untuk mendukung kegiatan wisata dengan tetap memprioritaskan masyarakat sekitar sebagai bagian yang penting bagi terlaksananya kegiatan ekowisata. Ketersediaan sarana prasarana penunjang seperti fasilitas wisata dan aksesibilitas yang ramah lingkungan diperlukan, dengan demikian wisatawan dapat memiliki kesempatan untuk menikmati objek wisata yang ada secara optimal (Latupapua, 2007).

terlalu jauh dari Kota Langgur Ibu Kota Maluku Tenggara juga menyimpan daya tarik wisata yang potensial untuk dinikmati oleh pegunjung dengan minat khusus terhadap goa (Cave). Goa H'wang menjadi salah satu objek wisata minat khusus, dengan keindahan alam yang dikelilingi hutan, memiliki kolam berair jernih dengan perpaduan stalagmit dan stalagtit yang menghiasi langit-langit dan dinding gua (Dinas Kominfo Kota Tual, 2019).

konservasi itu sendiri. Agar fungsi gua dapat dipertahankan maka dibutuhkan tidak hanya upaya untuk melestarikan melainkan pengembangan pariwisata gua itu sendiri (Gita dan Pitoyo, 2012).

Berdasarkan hal tersebut membuat penulis tertarik untuk melakukan penelitian ini dengan judul "Potensi dan Daya Dukung Fisik Kawasan Objek Wisata Gua H'wang Desa Letvuan Kecamatan Hoat Sorbay Kabupaten Maluku Tenggara".

Sorbay, Kabupaten Maluku Tenggara yang direncanakan akan dilakuan pada bulan September 2019 
Alat: Kamera, Laptop , Alat tulis menulis, GPS. Bahan yang digunakan adalah lembaran pertanyaan (kuisoner)

Jenis dan sumber data yang digunakan dalam penelitian adalah

1. Data sekunder diperlukan untuk melengkapi data primer yang diperoleh. Data sekunder Teknik Pengumpulan Data

a. Waktu Kunjungan : Pengamatan dilakukan selama 7 hari. Hari sabtu dan minggu menjadi waktu kunjungan terbanyak.

b. Wawancara : Dengan masyarakat, pengelola dan pengunjung untuk mendapat informasi dari objek yang diteliti baik itu berupa tanya jawab maupun melalui daftar pertanyaan yang telah dibuat peneliti. Responden yang diwawancarai sebanyak 80 orang.

c. Studi Literatur : Semua yang bersifat kepustakaan terkait penelitian.

$$
P=\frac{F}{N} \times 100 \%
$$

Keterangan :

$\mathrm{P}=$ Persentasi Pilihan

$\mathrm{F}=$ Frekuensi (jumlah Informan yang memilih alternative yang sama)

\section{Analisis Objek dan Daya Tarik Wisata} (ODTW)

Penilaian ODTW ditentukan dalam Pedoman Penilaian Daya Tarik Wisata (Departemen Kebudayaan dan Pariwisata, 2007). Pedoman ini memiliki beberapa komponen aspek. Komponen aspek yang digunakan dalam kasus ini daya tarik,

\section{$\mathbf{S}=\mathbf{N} \times \mathbf{B}$}

Keterangan:

$\mathrm{S}=$ Skor atau nilai suatu kriteria

$\mathrm{N}=$ Jumlah nilai unsur-unsur pada kriteria

$\mathrm{B}=$ Bobot nilai

Langkah kedua adalah penentuan kategori penilaian. Kategori disusun berdasarkan jumlah total dari setiap dan seluruh penilaian. Dalam penelitian yang telah

$$
\text { Selang }=\frac{\text { Smax }- \text { Smin }}{\mathrm{K}}
$$

Keterangan :

Selang = nilai selang dalam penetapan selang kategori penilaian;

$\mathrm{S}_{\max }=$ nilai skor tertinggi;

$\mathrm{S}_{\min }=$ nilai skor terendah;

$\mathrm{K}$ = banyaknya kategori penilaian. didapat dari dinas atau instansi terkait dan hasil penelitian sebelumnya yang terkait dengan penelitian.

2. Data primer adalah data yang dikumpulkan untuk kebutuhan studi, yang diperoleh dari observasi dan pengamatan langsung, wawancara serta dokumentasi dilapangan.

Analisis data yang digunakan dalam penelitian ini adalah analisis deskriptif kualitatif. Oleh karena itu, analisis data dilakukan dengan cara menggolongkan data berdasarkan sampel dengan kondisi apa adanya, tanpa melakukan analisis dan kesimpulan secara generalisasi selain itu proses pengolahan data juga dilakukan dengan skoring dan tabulasi. Untuk mendapatkan persentasi dari setiap frekuensi jawaban informan digunakan rumus (Ema \& Widodo, 2000):

$\mathrm{N}=$ Jumlah informan keseluruhan $100 \%$ Maka dari hasil tersebut didapatkan skor rata-rata dan di masukkan kedalam tingkat kategori.

aksesibilitas, kondisi lingkungan sosial ekonomi, akomodasi serta sarana dan prasarana penunjang. Pengambilan data dilakukan melalui mengisi kriteria yang sesuai dengan kondisi dan gambaran kawasan. Beberapa langkah dalam menentukan penilaian. Langkah pertama adalah penentuan nilai skor dengan persamaan (Departemen Kehutanan,2007).

dilakukan oleh Oktadiyani (2006), kategori penilaian akan dihitung dengan menggunakan persamaan sebagai berikut:
Penelitian ini menggunakan lima tingkat kategori, yaitu sangat baik, baik, sedang, buruk, dan sangat buruk (Tabel 1). Langkah ketiga adalah memasukkan total skor dari penilaian (dari langkah pertama) ke dalam 
kategori penilaian. Penentuan kategori dilakukan berdasarkan selang yang telah

dilakukan. Berdasarkan kategori, dapat diketahui gambaran dari kondisi kawasan.

Tabel 1. Kategori Penilaian ODTW

\begin{tabular}{ccc}
\hline No & Kategori Derajat & Interval \\
\hline 1 & Sangat baik & $514-600$ \\
\hline 2 & Baik & $428-513$ \\
\hline 3 & Sedang & $342-427$ \\
\hline 4 & Buruk & $256-341$ \\
\hline 5 & Cukup buruk & $170-255$ \\
\hline
\end{tabular}

Analisis Daya Dukung Fisik Kawasan

1. Daya dukung fisik (Physical Carrying Capacity/PCC)

Perhitungan daya dukung fisik dilakukan untuk mengetahui jumlah maksimal wisatawan secara fisik sehingga akan diketahui ambang batas jumlah maksimum wisatawan per rotasi kunjungan. Apabila hal tersebut melampaui

$$
\mathrm{PCC}=\mathrm{A} \times \frac{1}{B} \times \mathrm{Rf}
$$

Keterangan:

PCC = daya dukung fisik (Physical Carrying Capacity)

$\mathrm{A}=$ Luas area yang digunakan untuk wisata $\left(\mathrm{m}^{2}\right)$

Nilai Faktor Rotasi (RF) merupakan jumlah kunjungan harian yang dari batas normal, maka akan mengurangi kenyamanan dan kepuasan wisatawan dalam berwisata (Lucyanti, 2013 dalam Rahmat, 2016). Adapun metode yang dapat digunakan untuk mengetahui daya dukung fisik wisata alam gua H'wang yaitu menggunakan metode Cifuentes (1992) dengan rumus (Fandeli, 2002).

$\mathrm{B}=$ Luas area yang dibutuhkan oleh seorang wisatawan untuk berwisata dengan tetap memperoleh kepuasan dan tidak merusak lingkungan $\mathrm{Rf}=$ Faktor rotasi.

diperbolehkan ke satu lokasi, didapat dari perhitungan

$$
\text { Fakor Rotasi }(R F)=\frac{\text { Masa Buka }}{\text { Waktu Rata }- \text { Rata Kunjungan }}
$$

Nilai PCC merupakan nilai dasar yang digunakan untuk menghitung daya dukung kawasan berikutnya.

\section{HASIL DAN PEMBAHASAN}

\section{Potensi Daya Tarik Objek Wisata Gua H'wang}

Berdasarkan tabel di atas, jenis flora dan fauna yang ada memberikan daya tarik tersendiri dari objek wisata gua ini. Jenis-jenis flora yang ada membuat pemandangan di sekitar gua ini memberi kesan alami ketika dikunjungi pengunjung. Hal ini dikarenakan flora yang ada memiliki posisi yang saling berdekatan rapat sehingga gua ini seperti berada didalam hutan, Sehingga memberikan kenyamanan bagi para pengunjung karena udara di objek wisata ini sangat sejuk. Sedangkan jenis fauna yang ada membuat suasana di objek wisata ini lebih menarik dan terkesan lebih tenang. Hal ini dikarenakan pengunjung dapat melihat satwa burung beraktivitas serta pengunjung dapat mendengarkan kicauan-kicauan burung hal ini membuat suasana di Gua H'wang sangat nyaman. Dengan suasana yang tenang dan membuat para pengunjung merasa nyaman ini, dapat membuat para pengunjung dapat melepaskan kepenatan akibat aktivitas atau kesibukan lain yang dikerjakan. 


\section{Kriteria Penilaian Objek dan Daya Tarik Objek Wisata Alam}

\section{Daya Tarik Wisata}

Berdasarkan Undang-Undang Republik Indonesia No.10 tahun 2009, daya tarik wisata dijelaskan sebagai sesuatu yang memiliki keunikan, kemudahan, dan nilai yang berupa keanekaragaman kekayaan alam, budaya, dan hasil buatan manusia yang menjadi sasaran atau kunjungan wisatawan. Daya tarik objek wisata Gua H'wang ini tergolong dalam daya tarik wisata alam (natural attraction) karena meliputi pemandangan alam daratan, pemandangan alam lautan, pantai, iklim dan cuaca.

Dari hasil pengamatan langsung serta wawancara dengan pengunjung, berdasarkan penilaian yang dilakukan terhadap objek wisata Gua H'wang sebagai lokasi penilaian, maka hasil penilaian daya tarik wisatanya sebesar 410 dengan persentase 68,33\% yang menunjukan bahwa objek wisata Gua H'wang memiliki daya tarik yang sedang. Berdasarkan perhitungan penilaian daya tarik objek wisata dapat dilihat pada tabel berikut:

Tabel 2. Daya Tarik Wisata

\begin{tabular}{clccc}
\hline No & \multicolumn{1}{c}{ Unsur } & Nilai & Bobot & $\begin{array}{c}\text { Nilai X } \\
\text { Bobot }\end{array}$ \\
\hline 1 & Keunikan Dan Kelengkapan & 20 & 3 & 60 \\
\hline 2 & Keaslian & 30 & 1 & 30 \\
\hline 3 & Keindahan/Keragaman & 20 & 5 & 100 \\
\hline 4 & Keutuhan Tata Lingkungan & 25 & 4 & 100 \\
\hline 5 & Kepekaan & 30 & 4 & 120 \\
\hline \multicolumn{1}{r}{ Jumlah } & & & 410 \\
\hline & Nilai Kriteria 410/600x 100 & $=$ & $68,33 \%$ \\
\hline
\end{tabular}

Sumber: Data Primer (2019)

1. Keunikan Dan Kelengkapan

Keunikan dan kelengkapan merupakan salah satu daya tarik pada suatu objek wisata yang membuat pengunjung tertarik dan datang untuk mengunjungi objek wisata tersebut. Berdasarkan penilaian ODTW mengenai keunikan dan kelengkapan objek wisata Gua H'wang, didapat nilai 20 dari sub unsur yang ada pada kriteria penilaian yang di dalamnya hanya terpilih 3 sub unsur. Sub unsur ini

\section{Keaslian}

Keaslian dari suatu objek wisata adalah suatu aspek penting yang dapat dilihat dan dirasakan secara langusng oleh pengunjung. Penilaian ODTW mengenai keaslian objek wisata Gua H'wang ini mendapatkan nilai 30. Nilai ini diperoleh dari pendapat pengunjung yang menyatakan bahwa objek wisata ini masih asli berdasarkan wawancara secara langsung dengan pengunjung. Objek wisata 3. Keindahan/Keragaman diperoleh berdasarkan wawancara dengan pengunjung dan diubah menjadi bobot penilaian pada tabel yang kemudian dikalikan sehingga mendapatkan nilai 60. Objek wisata Gua H'wang memiliki daya pesona seperti susunan stalaktit dan stalagnit yang bervariasi ukurannya serta air gua yang sangat jernih dan berwarna biru sehingga membuat objek wisata ini unik dan sulit ditemukan di tempat lain khususnya di provinsi Maluku.

Gua H'wang merupakan salah satu objek wisata yang masih asli/alami karena belum adanya perubahan lingkungan, objek wisata ini masih dikelilingi pepohonan sehingga seperti berada didalam hutan sehingga membuat pemandangannya sangat indah serta kicauan burung membuat pengunjung yang datang ke Gua H'wang nyaman dan merasakan ketenangan. 
Keindahan/keragaman merupakan daya tarik yang disajikan dari suatu objek wisata dan dirasakan secara langsung oleh alat indra manusia. Berdasarkan penilaian ODTW mengenai keindahan/keragaman objek wisata Gua H'wang mendapat nilai 20 dari sub unsur yang ada pada kriteria penilaian yang didalamnya hanya terpilih 4 sub unsur. Sub unsur yang ada ini peneliti peroleh 4. Keutuhan Tata Lingkungan

Keutuhan tata lingkungan di lokasi wisata akan menambah minat pengunjung untuk mengunjungi kembali lokasi wisata tersebut. Berdasarkan penilaian ODTW mengenai keutuhan tata ruang objek wisata Gua H'wang di dapat nilai 25 dari sub unsur yang ada pada kriteria penilaian yang di dalam nya hanya terpilih 4 sub unsur. Sub unsur ini diperoleh berdasarkan wawancara dengan pengunjung

5. Kepekaan

Kepekaan dari suatu objek wisata harus diperhatikan oleh pengunjung karena dari setiap objek wisata memiliki sejarah dan halhal yang tidak boleh dilakukan atau dilanggar pada saat melakukan kunjungan di objek wisata tersebut. Berdasarkan penilaian ODTW mengenai kepekaan Objek wisata Gua H'wang didapat nilai 30 dari sub unsur yang

a. Nilai Pengetahuan

Berdasarkan wawancara dengan pengunjung, objek wisata Gua H'awang memiliki nilai pengetahuan seperti sejarah mengenai Gua H'wang dan dapat dijadikan sebagai objek penelitian.

b. Nilai Sejarah

Objek wisata Gua H'awang memiliki nilai sejarah dari cerita yang tersebar di daerah sekitar, awal mulanya ada seorang bapak dan dua ekor anjingnya yang sedang berburu, tiba-tiba bapak ini merasa haus dan minum di air gua namun bapak ini mengeluarkan kat-kata yang tidak senonoh Berdasarkan wawancara dengan masyarakat, pengelola dan pengunjung, objek wisata Gua H'awang memiliki nilai kepercayaan. Masyarakat sekitar dan pengunjung ada yang memberikan sesajen dan juga percaya bahwa di objek wisata Gua H'awang mempunyai hal-hal berdasarkan wawancara dengan pengunjung dan diubah menjadi bobot penilaian yang kemudian dikalikan mendapatkan nilai 80 . Objek wisata Gua H'wang memiliki susunan stalaktit dan stalaknit serta memiliki air gua yang jernih dan berwarna biru membuat panorama di gua ini sangat menarik, sehingga dapat menambah keindahan pada objek wisata ini.

dan di ubah menjadi bobot penilaian yang kemudian dikalikan mendapatkan nilai 100 . Kawasan wisata Gua H'wang merupakan lokasi wisata yang nyaman karena masih terlindung pepohonan membuat pengunjung dapat menghirup udara yang bersih dan merasakan hawa yang sejuk, bebas dari bau yang mengganggu, bebas dari kebisingan, jauh dari kegiatan industri serta kurangnya lalu lintas yang mengganggu.

ada pada kriteria penilaian yang di dalam nya hanya terpilih 4 sub unsur. Sub unsur ini diperoleh berdasarkan wawancara dengan pengunjung dan diubah menjadi bobot penilaian yang kemudian $d$ kalikan mendapatkan nilai 120. Objek wisata Gua H'wang merupakan objek wisata yang memiliki nilai-nilai sebagai berikut :

kemudian bapak ini menjadi batu jadilah Gua Hantu atau dengan bahasa daerah sekitar Gua H'wang.

c. Nilai Pengobatan

Berdasarkan wawancara dengan masyarakat, pengelola dan pengunjung, objek wisata Gua H'awang memiliki nilai pengobatan. Masyarakat sekitar dan pengunjung percaya bahwa air pada gua dapat mnyembuhkan penyakit, yang pernah terjadi ada seorang pengunjung yang menderita penyakit kulit dan gatal-gatal setelah mandi di air gua tidak berselang lama kemudian langsung sembuh.

d. Nilai Kepercayaan

yang mistis hal ini membuat setiap pengunjung yang datang berkunjung di Gua H'wang tidak diperbolehkan mengeluarkan kata-kata kotor dan membuat hal-hal yang tidak senonoh pada saat melakukan aktivitas berwisata di objek wisata ini. 


\section{Aksesibilitas}

Menurut Tamin (2000) dalam Azis dan Asrul (2018), aksesibilitas adalah suatu ukuran b. kenyamanan atau kemudahan mengenai cara lokasi tata guna lahan berinteraksi satu sama lain dan mudah atau susahnya lokasi tersebut dicapai melalui system jaringan transportasi. Faktor-faktor yang ada pada aksesibilitas ini dapat membantu mempermudah pengunjung untuk bepergian dari tempat tinggal pengunjung ke lokasi objek wisata yang akan dikunjunginya. Dalam bukunya, Azis dan Asrul (2018) mengemukakan bahwa aksesibilitas dipengaruhi oleh beberapa faktor antara lain:

a. Jarak

Faktor jarak dikatakan berpengaruh terhadap aksesibilitas dengan tingkat yang beragam, mulai dari tinggi sampai rendah. Dikatakan tinggi jika jarak antara dua wilayah yang saling berhubungan itu dekat dan dikatakan rendah jika jarak antar dua wilayah yang saling berhubungan jauh.

b.Waktu

Waktu tempuh merupakan kinerja yang lebih baik dibandingkan jarak. Jika waktu tempuh semakin cepat maka aksesbilitas tinggi dan begitupun sebaliknya. Selain itu, kondisi jalan dan tipe jalan juga dapat mempengaruhi waktu yang ditempuh sehingga dapat mempengaruhi juga aksesibilitas dalam mengunjungi suatu objek wisata yang ada. Faktor tersebut sangat penting dalam mendorong potensi pasar suatu objek. Aksesibilitas membahas tentang jarak, kondisi jalan, dan waktu tempuh dari pusat kota. Untuk menuju lokasi wisata membutuhkan waktu 20 menit dari pusat kota dengan menggunakan kendaraan pribadi roda empat/roda dua. Penilaian untuk aksesibilitas menuju objek wisata Gua H'wang dapat dilihat pada tabel dibawah ini.

Tabel 3. Aksesibilitas

\begin{tabular}{|c|c|c|c|c|}
\hline No & Unsur & Nilai & Bobot & $\begin{array}{c}\text { Nilai X } \\
\text { Bobot }\end{array}$ \\
\hline 1 & Kondisi jalan & 30 & 5 & 150 \\
\hline 2 & Jarak & 20 & 5 & 100 \\
\hline 3 & Tipe jalan & 25 & 5 & 125 \\
\hline 4 & Waktu & 30 & 5 & 150 \\
\hline & \multicolumn{2}{|c|}{ Jumlah } & & 525 \\
\hline & \multicolumn{2}{|c|}{ Nilai Kriteria 525 / $600 \times 100 \%$} & $=$ & $87,5 \%$ \\
\hline
\end{tabular}

Sumber : Data Primer (2019)

Berdasarkan hasil penelitian kriteria aksesibilitas maka objek wisata Gua H'wang memiliki potensi yang baik karena memiliki nilai sebesar 525 dan persentase $87,5 \%$. Penilaian mengenai kondisi jalan menuju objek wisata Gua H'wang dapat dilihat pada tabel di atas bahwa kondisi jalannya baik karena bentuk jalannya aspal dan tidak berlubang dan mendapatkan nilai 30. Dengan kondisi jalannya yang baik ini dapat memberi kemudahan bagi pengendara roda empat/dua dalam menempuh perjalanan menuju Gua H'wang tersebut. Selain itu, jarak jalan darat yang ditempuh sejauh $10-15 \mathrm{~km}$ dari pusat kota artinya jalan menuju objek wisata Gua H'wang tidak terlalu

\section{Kondisi Linkungan Sosial Ekonomi}

Penilaian kriteria kondisi lingkungan sosial ekonomi sangat diperlukan untuk mendukung potensi pasar wisata alam. Hal ini dapat dibantu penilaian kriteria ini sehingga jauh. Hal ini membuat unsur jarak pada objek wisata ini mendapatkan nilai 20 dengan lebar jalan aspal $<3 \mathrm{~m}$ mendapatkan nilai 25, dan waktu yang ditempuh dari pusat Kota Kabupaten yakni 20 menit atau masuk dalam kategori 1>2 jam mendapatkan nilai 30 . Dengan penilaian yang telah didapat, akses menuju objek wisata ini sudah sangat mudah membuat pengunjung nyaman dalam melakukan perjalanan menuju objek wisata. Para pengunjung tidak merasa kelelahan ketika berada di dalam perjalan menuju ke tempat objek wisata Gua H'wang tersebut.

dapat mendorong masyarakat lokal dalam artian masyarakat ikut terlibat dalam pengelolaan objek wisata tersebut untuk kesejahteraan masyarakat itu sendiri. Dengan begitu masyarakat lokal akan terlibat aktif dalam meningkatkan daya tarik dari objek 
wisata ini dengan mendukung potensi pasar wisata alam yanga da. Penilaian kriteria kondisi lingkungan sosial ekonomi dimulai pada radius $5 \mathrm{~km}$ dari batas kawasan intensife use atau jarak terdekat dari objek wisata.

Tabel 4. Kondisi Lingkungan Sosial Ekonomi

\begin{tabular}{clccc}
\hline No & \multicolumn{1}{c}{ Unsur } & Nilai & Bobot & $\begin{array}{c}\text { Nilai X } \\
\text { Bobot }\end{array}$ \\
\hline 1 & Tata ruang wilayah objek & 30 & 5 & 150 \\
\hline 2 & Tingkat Pengangguran & 30 & 5 & 150 \\
\hline 3 & Mata Pencaharian Penduduk & 20 & 5 & 100 \\
\hline 4 & Ruang Gerak Pengunjung (ha) & 10 & 5 & 50 \\
\hline 5 & Pendidikan & 30 & 5 & 150 \\
\hline 6 & Tingkat Kesuburan Tanah & 25 & 5 & 125 \\
\hline 7 & Sumber Daya Alam & 20 & 5 & 100 \\
\hline 8 & Tanggapan Masyarakat Terhadap & 20 & 5 & 100 \\
\hline$\quad$ Pengembangan OWA & & & 925 \\
\hline & $\quad$ Jumlah & & $77,08 \%$ \\
\hline
\end{tabular}

Sumber : Data Primer (2019)

Penilaian kriteria Kondisi Lingkugan Sosial Ekonomi objek wisata Gua H'wang untuk tata ruang lahan wilayah objek sudah ada dan sesuai karena objek wisata ini memang sudah ada sejak lama dan letaknya sesuai karena objek ini dikelilingi hutan dan jauh dari pemukiman penduduk, mendapatkan nilai 30 . Untuk tingkat pengangguran di daerah sekitar objek rendah karena $>15 \%$, berdasarkan data yang diberikan dari staf ohoi tingkat pengangguran sebanyak $40 \%$ dan mendapatkan nilai 30. Kemudian, mata pencaharian penduduk sebagian besar adalah petani dan berkebun dan mendapatkan nilai 20. Sedangkan tingkat pendidikan, sebagian besar lulus tingkat SMA ke atas mendapatkan nilai 30. Ruang gerak pengunjung di objek wisata ini tidak terlalu luas karena luasan objek wisata ini diperkirakan kurang lebih $600 \mathrm{~m}^{2}$ dan mendapatkan nilai sebesar 10. Tanah yang ada pada objek wisata ini sedang atau tidak terlalu subur karena rata-rata tanah di daerah

\section{Akomodasi}

Akomodasi adalah suatu yang disediakan untuk memenuhi kebutuhan, misalnya tempat menginap atau tempat tinggal sementara bagi orang yang bepergian. Menurut Kurnia dan Miskanag (2018), akomondasi merupakan salah satu sarana pendukung sektor pariwisata yaitu sarana untuk menyediakan pelayanan penginapan dilengkapi dengan kepulauan kei kecil dilapisi dengan karang hal ini membuat tingkat kesuburan tanah mendapatkan nilai 25. Sumber daya alam yang ada pada objek wisata ini masih sangatlah baik hal ini membuat sumber daya alam yang ada pada sekitaran objek masuk dalam kategori potensial karena sangat mendukung keberadaan dari objek wisata gua ini, mendapatkan nilai 20. Masyarakat cukup mendukung mengenai pengembangan objek wisata alam ini karena tidak semua masyarakat dilibatkan langsung dalam proses pengembangan objek wisata ini dan dalam mengelola objek wisata ini pun hanya masyarakat yang dipilih dari pihak ohoi, hal ini membuat tanggapan masyarakat mengenai pengembangan objek wisata mendapat nilai 20 . Dan untuk kondisi lingkungan sosial ekonomi di daerah sekitar masuk dalam kategori cukup baik dengan jumlah nilai sebesar 925 dan persentase yang didapat adalah $77,08 \%$.

pelayanan makan dan minum serta jasa lainnya. Dalam kepariwisataan akomodasi merupakan suatu industri, jadi pengertian industri akomodasi adalah suatu komponen industri pariwisata, karena akomodasi dapat berupa suatu tempat atau kamar dimana orangorang/pengunjung/ wisatawan dapat beristirahat/menginap/tidur, mandi, makan dan minum serta menikmati jasa pelayanan dan 
hiburan yang tersedia (Evita, Sirtha dan Sunarta, 2012).

Berdasarkan definisi akomodasi di atas, maka dapat disimpulkan bahwa adanya akomodasi pada suatu objek wisata sangatlah penting. Hal ini dikarenakan dapat menambah daya tarik objek wisata ada melalui kepuasan para wisatawan dalam mengunjungi objek wisata tersebut. Selain itu, hal ini akan membawa dampak yang baik.

Tabel 5. Akomodasi

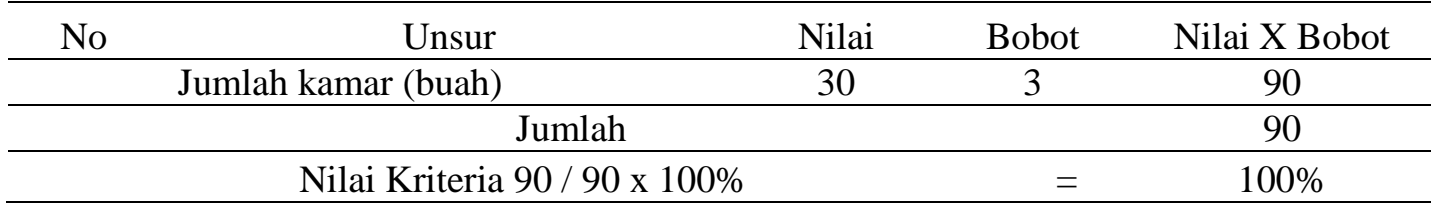

Sumber : Data Primer (2019)

Akomodasi dengan radius $15 \mathrm{~km}$ dari objek wisata Gua H'wang tepatnya di Langgur terdapat penginapan dan hotel dengan jumlah kamar lebih dari 100 (buah) dan mendapatkan nilai 30. Maka dari perhitungan yang didapat untuk penilaian terhadap akomodasi dengan

\section{Sarana dan Prasarana}

Sarana dan prasarana merupakan salah satu faktor penting yang sangat menunjang pertumbuhan industri pariwisata. Sarana prasarana harus ada dalam suatu kawasan wisata untuk menciptakan kepuasan wisatawan. Sarana dan prasarana dapat menjadi salah satu penunjang agar daya tarik wisata di kawasan ini diminati oleh wisatawan. Karena apabila sarana dan prasarana tidak dikembangkan dengan baik berakibat berkurangnya wisatawan yang berkunjung (Way, Wuisang dan Supardjo, 2016). Hal ini dikarenakan banyak para wisatawan di zaman sekarang ini selalu mempertimbangkan sarana dan prasaran di tempat wisata yang ingin dikunjunginya sebagai tempat berlibur. Tentunya para wisatawan yang menyempatkan radius $15 \mathrm{~km}$ sangat baik dan diperoleh nilai sebesar 90 dengan persentase sebesar $100 \%$. Dengan adanya jumlah akomodasi yang memadai para pengunjung dapat lebih mudah mendapatkan tempat untuk beristirahat ketika mengunjungi objek wisata Gua H'wang.

waktunya untuk berlibur, memiliki besar harapan agar dapat puas dengan pilihannya dalam berwisata. Sehingga, sarana dan prasarana ini sangat penting untuk mendukung daya tarik sebuah tempat wisata yang ada.

Hal-hal yang menyangkut dengan sarana dan prasarana menunjang objek wisata. prasarana seperti jalan, jembatan, areal parkir, jaringan listrik, jaringan air minum, jaringan telpon, jaringan daienase, sistem saluran pembuangan limbah, dermaga/pelabuhan tambat dan helipat. Sedangkan sarana penunjang seperti akomodasi, rumah makan/minum, sarana wisata tirta, sarana wisata budaya, sarana angkutan umum dan kios cinderamata. Penilaian dapat dilihat pada tabel berikut:

Tabel 6. Sarana Prasarana Penunjang

\begin{tabular}{ccccc}
\hline No & Unsur & Nilai & Bobot & Nilai X Bobot \\
\hline 1 & Prasarana & 30 & 3 & 90 \\
\hline 2 & Sarana Penunjang & 20 & 3 & 60 \\
\hline \multicolumn{7}{c}{ Nilai Kriteria 150/ $180 \times 100 \%$} & & 150 \\
\hline \multicolumn{2}{c}{ Jumlah } & $=$ & $83,33 \%$ \\
\hline
\end{tabular}

Sumber : Data Primer (2019)

Prasarana yang tersedia pada objek wisata Gua H'wang adalah sebagai berikut: jalan, areal parkir, jembatan, dermaga/pelabuhan, jaringan air minum, jaringan telpon dan mendapatkan nilai 30 dari sub unsur yang ada pada kategori pilihan berdasarkan pengamatan pada objek penelitian.
Untuk sarana penunjang yang tersedia seperti rumah makan dan sarana angkutan umum adapun sarana penunjang lainnya seperti gazebo, kamar mandi dan tempat sampah dan mendapatkan nilai 20 dari sub unsur yang ada pada kategori pilihan berdasarkan pengamatan pada objek penelitian. Hal ini membuat 
prasarana dan sarana penunjang yang ada pada objek wisata ini masuk dalam kategori baik karena mendapatkan nilai sebesar 150 dengan presentase $83,33 \%$, dengan tersedianya sarana

\section{KESIMPULAN}

Berdasarkan hasil penelitian dapat disimpulkan bahwa yaitu

1. Potensi Daya tarik yang dapat dinikmati oleh pengunjung adalah panorama sekitar goa yang masih terkesan alami, dan memiliki keragaman jenis pohon dan satwa, juga ditunjang dengan interior goa dalam bentuk stalatit dan stalamit.

\section{DAFTAR PUSTAKA}

Akliyah, L. S., \& Umar, M. Z. (2013). Analisis Daya Dukung Kawasan Wisata Pantai

Anik, I., \& Fandeli, C. (2004). Kajian Potensi dan Pengembangan Ekowisata Goa Pada

Azis, R., \& Asrul. (2018). Pengantar Sistem dan Perencanaan Transportasi. Yogyakarta: Deepublish.

Baulu, H. (2013). Studi Tentang Potensi Air Terjun Waai Sebagai Objek Wisata alam Di Negeri Waai Kecamatan Salahutu Kabupaten Maluku Tengah (skripsi).

Departemen Kehutanan. (2003). Pedoman Analisis Daerah Operasi Objek dan Daya Tarik Wisata Alam (ADOODTWA).

Departemen Kehutanan. (2007). Kumpulan Peraturan dan Pedoman Pariwisata Alam. Pelatihan Pariwisata Alam 31 Oktober - 2 November 2007. Direktorat

Dinas Kominfo Kota Tual. (24 Januari 2019). Destinasi Wisata di Kepulauan Kei yang

Domo, A. M., Zulkarnaini., \& Yoswaty, D. (2019). Analisis kesesuaian dan daya dukung kawasan wisata pantai (Studi pantai indah sergang laut di Pulau

Dwi, A. N. (2008). "Pengembangan Kompetensi Paedagogik Guru Pendidikan Kewarganegaraan yang Sudah Bersertifikasi (Studi Kasus pada prasarana yang sudah ada diharapkan dapat membuat pengunjung nyaman untuk melakukan aktivitas wisata dan berkeinginan untuk berkunjung kembali.

2. Daya dukung fisik kawasan objek wisata Gua dalam menampung pengunjung berkisar 110 orang/hari. Batas daya dukung tersebut belum melampaui batas daya dukung kawasan jika dihubungkan dengan jumlah kunjungan perhari yang hanya sekitar 20-30 pengunjung.

Sebanjar Kabupaten Alor dalam Mendukung Kawasan yang Berkelanjutan. Jurnal Perencanaan Wilayah dan Kota, 2(13), 1-8. Bandung: Universitas Islam Bandung.

Kawasan Karst Kabupaten Gunungkidul. Yogyakarta: Universitas Gadjah Mada.

Maluku: Program Studi Pendidikan Geografi Fakultas Keguruan dan Ilmu Pendidikan, Universitas Pattimura.

Wisata Alam dan Pemanfaatan Jasa Lingkungan. Jakarta: Direktorat Jendral Perlindungan Hutan dan Konsevasi Alam.

Mempesona. Dipetik 31 Juli, 2019, dari Wisata Kota Tual:

Singkep). Jurnal Dinamika Lingkungan Indonesia, 4(2), 109-116. ISSN 23562226.

Guru Pendidikan Kewarganegaraan di SMP Negeri 1 Wedi Kabupaten Klaten Tahun 2012/2013)". Skripsi S-1. Surakarta: Fakultas Keguruan dan Ilmu 
Pendidikan Universitas Muhamadiyah

Ema., \& Widodo, M. (2000). Konstruksi ke Arah Penelitian Deskriptif.

Yogyakarta: Ayyrrouz.

Evita, R., Sirtha, I. N., \& Sunarta, I. N. (2012). Dampak Perkembangan Pembangunan Sarana Akomodasi Wisata Terhadap

Fandeli, C. (2000). Pengusahaan Ekowisata. Yogyakarta: Universitas Gadjah Mada.

Fandeli, C. (2001). Dasar-Dasar Manajemen Kepariwisataan Alam. Yogyakarta: Liberty Offset.

Gita, H., \& Pitoyo, A. J. (2012). Kajian Potensi Gua Sebagai Arahan Wisata Minat Khusus Penelusuran Gua Di Pulau Nusakambangan. Jurnal Harmony, 1(3),

Hakim, L. (2004). Dasar-Dasar Ekowisata. Malang: Bayumedia.

Hermawan, H. (2017). Pengaruh Daya Tarik Wisata, Keselamatan dan Sarana Wisata Terhadap Kepuasan Serta Dampaknya Terhadap Loyalitas Wisatawan. Jurnal Media Wisata, 15(1), 562-577.

Kurnia., \& Miskanag. (2018). Teropong Indonesia: Memahami kondisi actual Marchelina, S. D. (2018). Studi Daya Dukung Fisik Kawasan Wisata Dan Persepsi Wisatawan Di Pusat Latihan Gajah Taman Nasional Way Kambas. Bandar Lampung: Universitas Lampung.

Mathieson, A., \& Wall, G. (1982). Tourism: Economic, Physical and Social Impact. New York: Longman Scientific and Technical.

Noor, D. (2014). Geomorfologi. Yogyakarta: Deepublish.

Oktadiyani P. (2006). Alternatif Strategi Pengelolaan Taman Wisata Alam Kawah Kamojang Kabupaten Bandung Propinsi Jawa Barat.. Departemen Konsevasi Sumberdaya Hutan dan Ekowisata. Bogor: Institut Pertanian Bogor.
Surakarta.

Pariwisata Berkelnjutan di Bali. Jurnal Ilmiah Pariwisata, 2(1), 109-222.

Fandeli, C. (2002). Perencanaan Kepariwisataan Alam. Yogyakarta: Fakultas Kehutanan Universitas Gadjah Mada.

1-14. $\quad$ Retrieved from http://lib.geo.ugm.ac.id/ojs/index.php/jbi /article/view/65/63.

perekonomial Indonesia). Jakarta Selatan: Republika Penerbit.

Latupapua, Y. (2007). Studi Potensi Kawasan dan Pengembangan Ekowisata di Tual Kabupaten Maluku Tenggara. Jurnal Agroforestri, 2(1), Maret 2007.

Rahmat, W. (2016). Studi Daya Dukung Ekowisata Air Terjun Wiyono di Taman Hutan Raya Wan Abdul Rachman Provinsi Lampung. Bandar Lampung: Universitas Lampung.

Ritchie, J. R. B., \& Crouch, G. I. (2003). The Competitive Destination: A Sustainable Tourism Perspective. Australia: CABI Publishing.

Rozak, H. A. (2017). Kualitas Daya Tarik Wisata, Kepuasan Dan Niat Kunjungan Kembali Wisatawan Mancanegara Jawa Tengah. Jurnal Pengembangan IlmuIlmu Pariwisata dan Perhotelan, 11(2), 1-12.

Sekar Indah Putri Barus, Pindi Patana, Yunus Afiffudin. 2013. Analisis Potensi Objek Wisata dan Kesiapan Masyarakat dalam Pengembangan Desa Wisata Berbasis 
Masyarakat di Kawasan Danau Linting Kabupaten Deli Serdang, Mahasiswa Program Studi Kehutanan, Fakultas Pertanian, Universitas Sumatera Utara, Jl. Tri Dharma Ujung No. 1 Kampus USU Medan 2015.

Siswantoro, H., Anggoro, S., \& Sasongko, D. P. (2012). Strategi Optimasi Wisata Massal Di Kawasan Konservasi Taman Wisata Alam Grojogan Sewu. Jurnal Ilmu Lingkungan, 10(2), 1-11. ISSN 1829-8907.

Sjaifuddin. (2004). Optimasi Daya Dukung Obyek Wisata di Taman Nasional Gede Pangrango. Bogor: Agricultural University.

Vanhove, N. (2005). The economics of tourism destinations. Oxford: The British Library.

Way, I. H., Wuisang, C. E. V., \& Supardjo, S. (2016). Analisis Kebutuhan Prasarana Dan Sarana Pariwisata Di Danau Uter Kecamatan Aitinyo Kabupaten Maybrat Propinsi Papua Barat. Jurnal Spasial: Perencanaan Wilayah dan Kota, 3(3), 27-37.

Wiweka, K. (2018). Analisis Produk Wisata di Taman Bumi Perkemahan Dan Graha Wisata Pramuka (Buperta) Cibubur Jakarta. Jurnal Ilmiah Hospitality Management, 5(2), 1-14. 
DOI: 10.30598/jhppk.2020.4.2.172

ISSN ONLINE: 2621-8798

Page 183 